\title{
Public Buses Decontamination by Automated Hydrogen Peroxide Aerosolization System
}

\author{
Attapol Arunwuttipong ${ }^{1}$, , Parinton Jangtawee $^{2}$, Viwat Vchirawongkwin ${ }^{3}$, Wiyong Kangwansupamonkon ${ }^{4}$, Kavin Asavanant ${ }^{5}$, \\ Sanong Ekgasit ${ }^{2,6 *}$ (iD) \\ ${ }^{1}$ Technopreneurship and Innovation Management Program, Graduate School, Chulalongkorn University, Bangkok, Thailand; \\ ${ }^{2}$ Department of Chemistry, Sensor Research Unit, Faculty of Science, Chulalongkorn University, Bangkok, Thailand; ${ }^{3}$ Department \\ of Chemistry, Faculty of Science, Chulalongkorn University, Bangkok, Thailand; ${ }^{4}$ National Nanotechnology Center, National \\ Science and Technology Development Agency, Khlong Luang, Phathum Thani, Thailand; ${ }^{5}$ Chulalongkorn Business School, \\ Chulalongkorn University, Bangkok, Thailand; ${ }^{6}$ Research Network NANOTEC-CU on Advanced Structural and Functional \\ Nanomaterials, Faculty of Science, Chulalongkorn University, Bangkok, Thailand
}

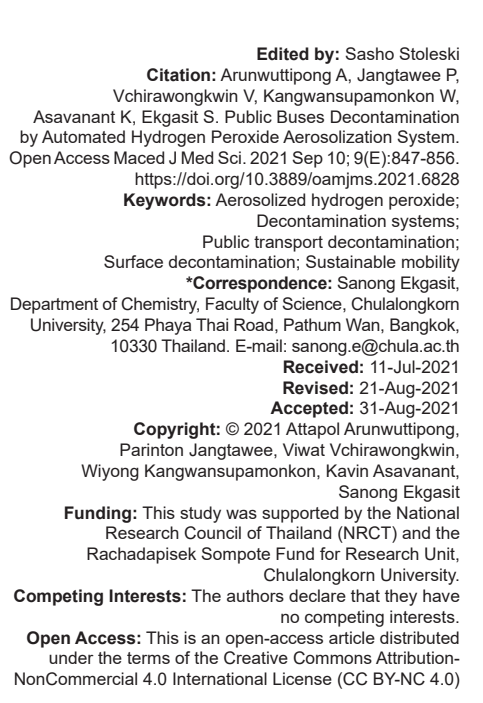

\section{Abstract}

BACKGROUND: Public transportation has been linked to an increase in the risk of coronavirus disease 2019 transmission. The effective decontamination system using aerosolized hydrogen peroxide can mitigate the transmission risk from using public transportation.

AIM: The aim of this study was to develop and validate an effective decontamination system for public transport.

METHODS: The experimental research was performed in 13 inter-city public buses. The aerosol generator with ultrasonic atomizer was used in the experiment. The validation process for disinfection was conducted using both a chemical indicator $(\mathrm{Cl})$ and spore discs biological indicator (inoculated with $10^{6}$ Geobacillus stearothermophilus enclosed in glassine envelopes). The Cls and biological indicators were marked by number and placed in nine locations on each bus. The decontamination cycle was developed by analyzed of various aerosolized and decomposition period. Both concentrations of hydrogen peroxide, $5 \%$ and $7 \%$, were used for comparison.

RESULTS: In an aerosolized period, both concentrations of hydrogen peroxide at 30 min were effective for sporicidal 6 -log reductions. The decontamination cycle totaled $100 \mathrm{~min}$, based on a $70 \mathrm{~min}$ average decomposition time.

CONCLUSIONS: The automated hydrogen peroxide aerosolized system is a highly effective and safe method of decontaminating public buses.

\section{Introduction}

The global coronavirus disease 2019 (COVID19) pandemic, caused by severe acute respiratory syndrome coronavirus 2 (SARS-CoV-2), originated in Wuhan (China) in December 2019 and has spread to over 200 countries. Most countries use preventive measures to control infection transmission, including physical distancing, wearing a face mask, prohibit crowd gathering, frequently cleaning hands with soap or alcohol-based hand sanitizers, social distancing, travel restriction, and lockdown. These counter measures have affected various industries and sectors in several ways. Public transport was also heavily affected by the outbreak. Several measures for public transportation, including advice to avoid public transport, and reduce the number of passengers to allow physical distancing, have led to an expected dramatic decrease in ridership (40-90\%) during the early period of the outbreak [1], [2], [3], [4]. The fear of being infected has resulted in reduced mobility and avoidance of public transport [5]. Zhang et al. [6] found that the largest share of public transport modals shifted to private cars during the pandemic. This decline in ridership has caused the financial instability of transit operators [7], [8], [9]. These effects not only affect behavioral change but also attitudes toward public transport. Some studies have expressed the concern of public returning to public transportation in post-COVID-19 [10], [11].

Public transport has been debated as an increased risk of COVID-19 transmission due to its confined spaces, limited ventilation, and prolongs duration time. The case report of the infection clusters on 
a tour bus in China with the index case that transmitted the virus to 23 of a total of 68 passengers [12]. Similarly, observations have been reported in another public bus with an index case transmitted to other ten people [13]. In addition, in-flight transmission has been reported; for example, 12 people were infected on a 325-passenger flight from Singapore to Zhenjiang, China [14], and 16 out of 217 passengers were infected on a flight from London to Hanoi, Vietnam [15].

The route of COVID-19 transmission is through droplet, fomite contact, and airborne transmission under special circumstances [16]. Fomite transmission is an indirect contact that occurs when non-infected people touch contaminated surfaces with their hands and subsequently touch their mouth or nose. Under certain conditions, fomite transmission can spread widely and rapidly. The transmission of pathogens by contaminated surfaces to the hands can be spread up to 14 individuals and by hand-to-hand sequentially up to six individuals [17]. A modeling study of the spread ability by fomite transmission in aircraft showed that most of the high-touch surfaces in the cabin were contaminated within 2 or $3 \mathrm{~h}$ [18]. Many studies have found environments contaminated with SAR-CoV-2 in both health-care settings [19], [20], [21], [22], [23] and non-health-care settings [24], [25], [26], [27], [28], [29]. The evidence showed that SARS-CoV-2 could persist on surfaces for several hours or days [30]. There have been reports of COVID-19 infection linked to fomite transmission [31], [32]. However, some researchers suggest that fomite transmission is a low risk, as most studies of environmental contamination do not present the real-life situation [33], [34]. Only SARS-CoV-2 RNA has been detected, with only few studies successful in culturing viable viruses from surfaces [35]. At present, there is limited evidence on the proportion of fomite transmission in SARS-CoV-2 infection. However, the new strains of SARS-CoV-2 have been shown to possess better transmissibility and may behave differently in fomite transmission [36]. Moreover, fomite transmission play an important role in the transmission of certain bacteria and viruses (e.g., Methicillin-resistant Staphylococcus aureus, SARS-CoV, and Norovirus) [37], [38], [39], [40].

A safe strategy for mitigating the risk of fomite transmission is implementing surface cleaning and disinfection. The researchers found that city disinfection was an important strategic policy to help prevent the spread of COVID-19 [41]. Surface cleaning and disinfection can be performed either by traditional manual methods or modern automated methods. There is strong evidence indicating that traditional cleaning and disinfection methods are not adequate for infection prevention and control. According to the previous studies, traditional methods only cover $40-60 \%$ of the surfaces that should be cleaned [42], [43]. To improve cleaning and disinfection, particularly in health-care settings, automated technologies are recommended to supplement traditional methods [44]. These modern technologies cannot be used in place of traditional methods because a traditional method is necessary to eliminate the visible dirt. Numerous technologies have been developed in an attempt to increase the cleaning and disinfection coverage area, such as spraying or fumigating disinfectants. Spaying of commonly used disinfectants such as hypochlorite-based products and quaternary ammonium compounds (Quats) is considered an effective method of microbial decontamination. However, the study discovered that trigger spray and electrostatic spray still had coverage area limitations [45]. Spraying disinfectant is ineffective at removing contaminants outside of direct spray zone [46]. In addition, spraying disinfection systems require human control, which could increase the risk of developing asthma and respiratory tract disease to users. Benzalkonium chloride (BAC) is one of the Quats common used for surface disinfection. The study found that BAC is not degradation rapidly and its antimicrobial effect last on the surface for days [47]. The residual of BAC even low concentration could cause skin irritation [48]. Gas fumigation such as formaldehyde and chlorine oxide is highly effective antimicrobial agents. However, these disinfectants pose health risks of cancers and respiratory diseases [49]. In a cost comparison of disinfectants with the same highdisinfection level efficiency, $7.5 \%$ hydrogen peroxide is found to be less expensive than $0.2 \%$ peracetic acid, $2 \%$ glutaraldehyde, and $0.55 \%$ ortho-phthalaldehyde when using with manual or automated methods [50].

Two of the most frequently used automated technologies are the ultraviolet germicidal irradiation (UVGI) system and the hydrogen peroxide $\left(\mathrm{H}_{2} \mathrm{O}_{2}\right)$ system. The UVGI system is well studied and used for air and surface disinfection in hospitals. The advantage of UVGI is that it is simple to use and leaves no residue, but the main limitation is that shadowing can result in a decrease in disinfection efficacy. Hence, in the complex room with potential shadow, $\mathrm{H}_{2} \mathrm{O}_{2}$ is preferred to the UVGI system [51]. Public buses contain areas that are out of sight, such as the area beneath the seat. The $\mathrm{H}_{2} \mathrm{O}_{2}$ system appears to be suitable for decontaminating public buses. In addition, $\mathrm{H}_{2} \mathrm{O}_{2}$ decomposes spontaneously into oxygen and water, which are non-toxic byproducts. New research has focused on decontamination methods that are both effective and environmental friendliness [52], [53].

There are two types of $\mathrm{H}_{2} \mathrm{O}_{2}$ systems: A hydrogen peroxide vapor (HPV) system and an aerosolized hydrogen peroxide (aHP) system. The aHP system is also known by the alternative name "dry mist hydrogen peroxide," which is misleading in terms of its properties [54]. Two typical HPV technology systems are the dry process (Steris Corporation, Ohio, and USA) and the wet process (Bioquell, Hampshire, and UK). The dry process operates without condensation and requires humidity control before operation. In general, the decontamination cycle for a dry process consists of four phases by (1) dehumidification, where 
relative humidity is reduced; (2) conditioning, where the vapor is released until reached desire concentration; (3) decontamination, where the vapor is steady released to keep the constant concentration, and (4) aeration, where the residual $\mathrm{H}_{2} \mathrm{O}_{2}$ is removed by a catalytic process. By contrast, the wet process does not require humidity control and therefore result in micro-condensation. However, the decontamination cycle is similar to dry system which consists of four phases: Conditioning, gassing, dwell, and aeration. The difference from the dry process is that no vapor is emitted during dwell phase, this permitting the peroxide to dwell on any surface exposed. Both HPV systems are produced by heating $30-35 \%$ liquid $\mathrm{H}_{2} \mathrm{O}_{2}$ to a vapor, while aHP uses a low concentration of $\mathrm{H}_{2} \mathrm{O}_{2}(5-7 \%)$ by pressure or ultrasonic injection. Another distinction is the process of $\mathrm{H}_{2} \mathrm{O}_{2}$ decomposition: HPV is the active aeration phase, while aHP is the passive phase in which the left aerosol decomposes naturally. According to their disinfection efficacy, the HPV system has been supported by many studies [55], [56], [57], while the use of the aHP system has been limited. Several studies have compared the effectiveness of HPV disinfection systems to aHP systems, indicating that HPV systems are more effective at disinfecting than aHP systems, despite concerns about the reliability of aHP systems [58], [59], [60]. On the contrary, Ali et al. [61] demonstrated that aHP decontamination was successful at inactivating pathogens and was comparable to HPV systems. HPV disinfection systems are widely used for disinfecting isolators, medical equipment, and room disinfection. By comparison, aHP disinfection system provides greater containment of $\mathrm{H}_{2} \mathrm{O}_{2}$ within an area of application [62], potentially eliminating the need to seal the door and window edges of the room. As a result, rooms that were not originally designed for vapor systems could be used with aHP [63]. Further, aHP has lower machine and maintenance costs and can be easily scaled.

$\mathrm{H}_{2} \mathrm{O}_{2}$ has long been used as a disinfectant and antiseptic. There have been few studies that using low $\mathrm{H}_{2} \mathrm{O}_{2}$ concentration for ingestion or breathing to treat diseases including such COVID-19 [64]. However, high levels of exposure, ingestion, or breathing can be extremely dangerous. Drinking high concentrations of $\mathrm{H}_{2} \mathrm{O}_{2}$ can be fatal or cause serious harm. Five people reported chest pain, stomach pain, difficulty breathing, and loss of consciousness after drinking $50 \mathrm{~mL}$ of $33 \% \mathrm{H}_{2} \mathrm{O}_{2}$ [65]. The US FDA has warned that drinking $35 \% \quad \mathrm{H}_{2} \mathrm{O}_{2}$ can cause gastrointestinal irritation or ulceration which may lead to death [66]. For inhalation, $\mathrm{H}_{2} \mathrm{O}_{2}$ concentration level $<1 \mathrm{ppm}$ is considered safe. Longitudinal studies of a worker exposed to $\mathrm{H}_{2} \mathrm{O}_{2}$ at concentrations $<1 \mathrm{ppm}$ revealed no effect on lung function [67]. However, inhalation of $\mathrm{H}_{2} \mathrm{O}_{2}$ at a concentration of $2.2 \mathrm{ppm}$ for $2 \mathrm{~h}$ was found to cause mild irritation, including nasal airway resistance.

The purpose of this study was to validate the disinfectant efficacy of aHP and to develop a decontamination cycle for public buses. Throughout the decontamination process, the concentration of residual $\mathrm{H}_{2} \mathrm{O}_{2}$ was monitored to ensure that it was $<1 \mathrm{ppm}$ at the end of the cycle. The permissible exposure limit of $\mathrm{H}_{2} \mathrm{O}_{2}$, according to the Occupational Safety and Health Administration, is $1 \mathrm{ppm}$ for an average of 8-h timeweighted averages [68]. $\mathrm{H}_{2} \mathrm{O}_{2}$ concentrations of $<1 \mathrm{ppm}$ would allow people to reenter the area in which it is being used.

\section{Materials and Methods}

\section{Aerosolized generator and disinfectants}

The ultrasonic aerosol generator with an injection rate of $20 \mathrm{~mL} / \mathrm{min}$ was used in the experiment. The generator features pre-set timing for the aerosolized period and delayed time prior release aerosol for safety to operators. The generator was placed in the center of the bus and was pre-set with different aerosolized period 16, 20, 25, and $30 \mathrm{~min}$. The windows and doors remain closed during the decontamination cycle. The two different concentrations of $\mathrm{H}_{2} \mathrm{O}_{2}$ were used to

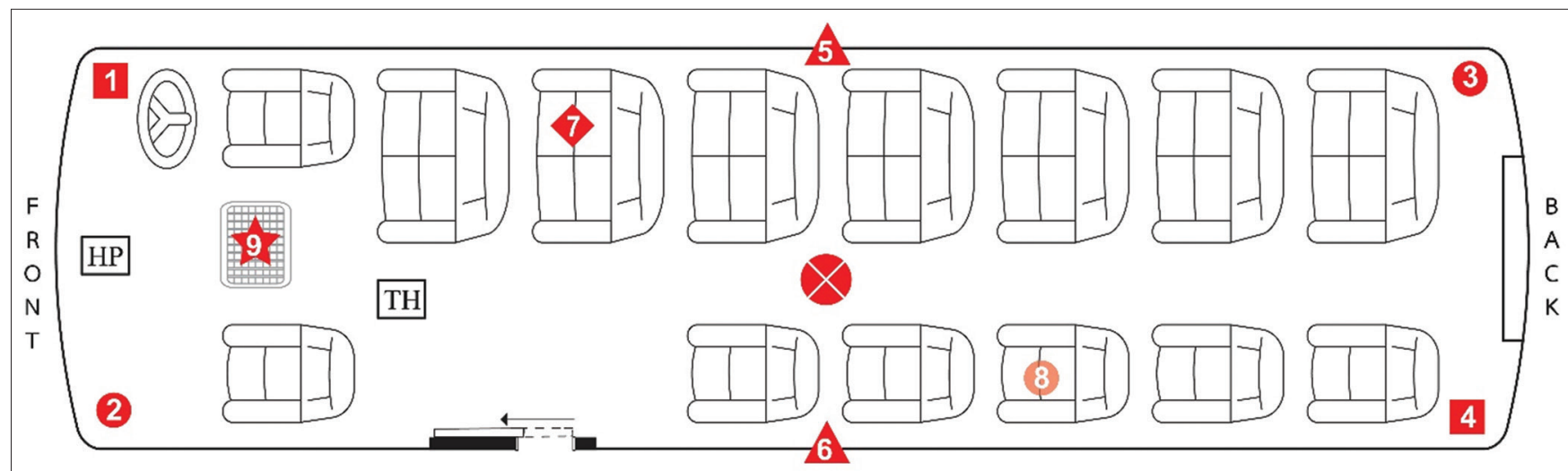

$\bigotimes$ aHP generator $\square$ ceiling; $\bigcirc$ floor; $\Delta$ wall face; on the seat; th air filter; $\amalg \mathrm{H}_{2} \mathrm{O}_{2}$ sensor; TH Temperature and Humidity sensor

Figure 1: The location of chemical indicators and biological indicators placement inside the public buses 
compare between $5 \% \mathrm{H}_{2} \mathrm{O}_{2}$ and $0.005 \%$ silver ions (Sanosil S010 and Sanosil AG) and solutions prepared by diluting $50 \% \mathrm{H}_{2} \mathrm{O}_{2}$ food grade (Interox $\mathrm{FG50}$ and Solvay Thailand) with deionized water to a final concentration of $7 \% \mathrm{H}_{2} \mathrm{O}_{2}$ solution.

\section{Decontamination process and validation}

The temperature and humidity were measured by a handheld meter placed inside the bus during the decontamination process (GSP-6, Elitech Technology Inc, USA, accuracy $\pm 0.5^{\circ} \mathrm{C}$, and $\pm 3 \% \mathrm{RH}$ ). The $\mathrm{H}_{2} \mathrm{O}_{2}$ sensor meter (CB-100, MembraporAG, Switzerland, and accuracy $\pm 3 \%$ ), with a range of 0-20 ppm, was placed inside the bus by the window to measure the residual $\mathrm{H}_{2} \mathrm{O}_{2}$. The duration after aerosolized period until $\mathrm{H}_{2} \mathrm{O}_{2}$ concentration is below $1 \mathrm{ppm}$ is considered to be the decomposition time which indicates that the decontamination process had ended. To validate the disinfection efficacy, chemical indicator (CI) strips (Comply ${ }^{\mathrm{TM}}$ Hydrogen Peroxide $\mathrm{Cl}$ 1248, 3M, USA) and biological indicator (BI) envelopes containing $2.30 \times 10^{6}$ Geobacillus stearothermophilus ATCC 7953 dried on stainless-steel metal discs sealed in glassine paper (Sterind Bio-indicator G. stearothermophilus, Micro
Biotech Inc., India) were marked by number and placed in hard-to-reach locations inside the buses on the floor, ceiling, wall faces, on the seat, and beneath the seat (Figure 1). At the end of the process, Cls and Bls were evaluated. $\mathrm{ACl}$ that changed its color from blue to pink was considered exposed to $\mathrm{H}_{2} \mathrm{O}_{2}$ and reported as a positive test. The $\mathrm{BI}$ was retrieved, and the envelope was opened. A disc was transferred to culture in Tryptic soy broth at $56^{\circ} \mathrm{C}$ for 7 days. Turbidity was observed for re-growth of the spores which indicating failure or positive test.

\section{Public buses}

This study was performed in 13 buses at the public bus station of Trat City (the eastern province of Thailand). The 20 seater air-conditioned bus with dimension $2 \mathrm{~m} \times 6.7 \mathrm{~m} \times 1.9 \mathrm{~m}(\mathrm{~W} \times \mathrm{D} \times \mathrm{H})$, an interior volume of $25.46 \mathrm{~m}^{3}$ was employed. The buses operated between Trat and Bangkok, with a distance $320 \mathrm{~km}$. Bangkok is the capital of Thailand and Trat is the major attraction tourist city. The total transit duration was approximately $6 \mathrm{~h}$, including stops at six locations along the route (Figure 2 ).

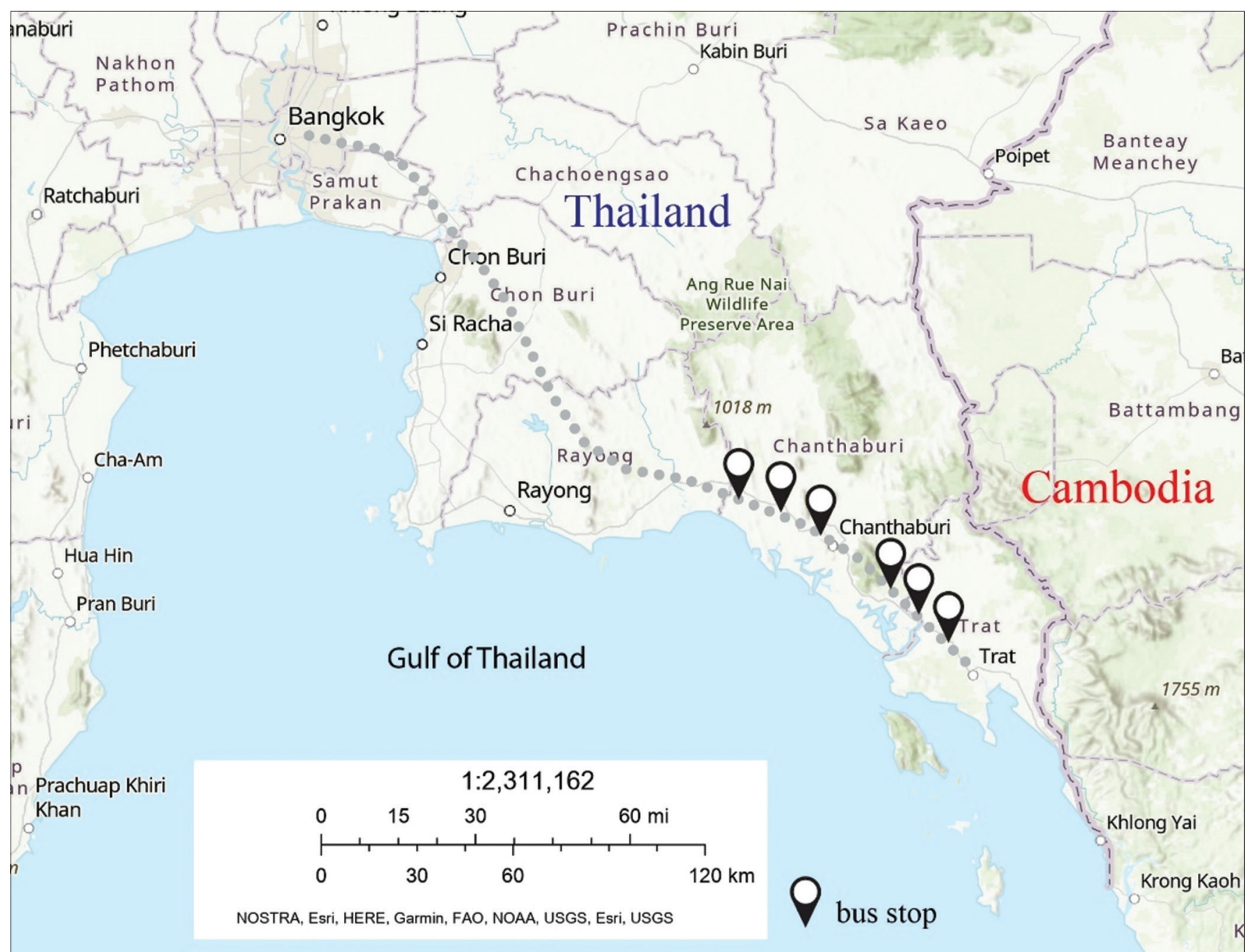

Figure 2: Inter-city bus route between Trat and Bangkok 


\section{Results}

During aerosol injection, the relative humidity increased, and the temperature decreased until the aerosolized period was complete, at which point the relative humidity decreased (Figure 3 ). $\mathrm{H}_{2} \mathrm{O}_{2}$ concentrations increased during the decontamination process, and condensation was observed near the location of the generator. Each bus had nine Cls and $\mathrm{Bls}$, for a total of $117 \mathrm{Cls}$ and $117 \mathrm{Bls}$.

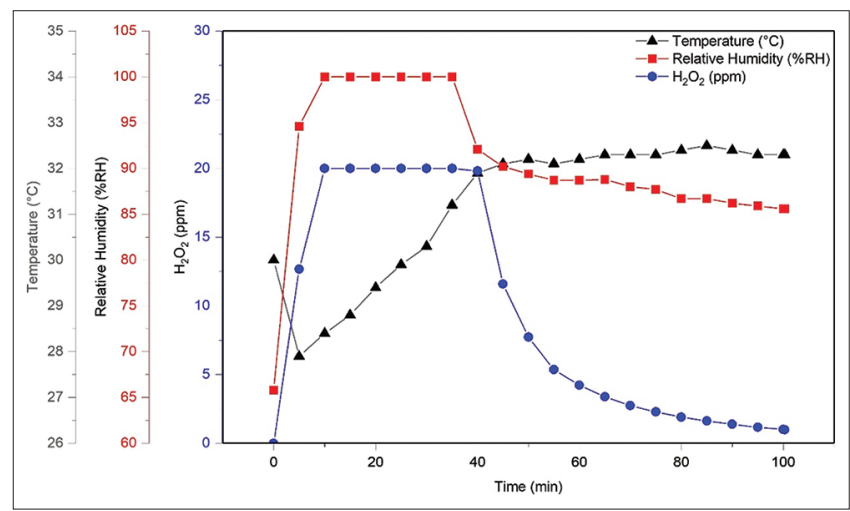

Figure 3: Temperature, relative humidity, and hydrogen peroxide concentration during decontamination cycle with $30 \mathrm{~min}$ aerosolized period

All Cls (100\%) were fully exposed to $\mathrm{H}_{2} \mathrm{O}_{2}$, while $89(76.06 \%)$ of the $117 \mathrm{Bls}$ demonstrated effective decontamination. At $16 \mathrm{~min}$, the aerosolized period was insufficient to disinfect all Bls. Exposure times of 20 and 25 min were insufficient to inactivate some BI locations (Table 1).

The exposure time of 30 min revealed effective inactive Bls at all locations, with either $5 \%$ or $7 \% \mathrm{H}_{2} \mathrm{O}_{2}$ concentrations. Decomposition time of $70 \mathrm{~min}(95 \%$ $\mathrm{Cl}$; 47-86 $\mathrm{min}$ ) combined with an exposure time of $30 \mathrm{~min}$ yielded a total of nearly $2 \mathrm{~h}$ as an effective decontamination cycle for the 20 -seater bus.

\section{Discussion}

$\mathrm{H}_{2} \mathrm{O}_{2}$ is a potent oxidizing agent. It is broadspectrum microbial activity against bacteria, viruses, molds, and spores by generating free hydroxyl radicals, leading to the oxidation of the lipid membranes, protein, and deoxyribonucleic acid of microorganisms. $\mathrm{H}_{2} \mathrm{O}_{2}$ in the vapor phase is a more potent protein oxidizer than $\mathrm{H}_{2} \mathrm{O}_{2}$ in the liquid phases [69].

In this study, we discovered that when the aerosol was injected, the relative humidity increased and remained plateaued until the injection was complete, at which point it decreased. Both the aHP and HPV systems can raise relative humidity during the aerosolized period. There have been two disagreements about the effect of humidity on the decontamination efficiency of both $\mathrm{H}_{2} \mathrm{O}_{2}$ systems [70]. High relative humidity has a negative impact on the decontamination efficiency of the HPV system, as areas with high humidity cannot contain high concentrations of $\mathrm{H}_{2} \mathrm{O}_{2}$. Condensation occurs when the vapor concentration of $\mathrm{H}_{2} \mathrm{O}_{2}$ is higher than its saturation level, which inhibits the homogenous distribution of the vapor. Thus, in a dry process system, the relative humidity has to be reduced prior to decontamination with $\mathrm{H}_{2} \mathrm{O}_{2}$. Dehumidification before using an aHP system has been shown to improve decontamination performance. In another point of contention, the efficiency of surface disinfection is dependent on condensation on the surface being decontaminated. High humidity has a greater impact on disinfection efficacy than low humidity. Therefore, in the wet process, humidity control before decontamination is not required. However, some studies have indicated that the humidity factor is a less important factor and that it may not be necessary to pre-condition by reducing humidity prior to decontamination [71]. In this study, no humidity control was performed before decontamination. The experiment was conducted in a real-life situation. The $\mathrm{H}_{2} \mathrm{O}_{2}$ sensor had a maximum reading of $20 \mathrm{ppm}$, but our objective was not to determine the relationship between the concentration and decontamination efficacy. The sporicidal efficacy resulted in a 6-log reduction. This study demonstrated the effectiveness of aHP in real-world scenarios. The lack of humidity control emphasizes the advantages of aHP over other systems in terms of ease of use.

According to the International Organization for Standardization (ISO) 11139:2018, a Cl is a "test system that reveals change in one or more pre-specified process variables based on a chemical or physical

Table 1: Results of aHP decontamination by chemical indicators and biological indicators at various aerosolized periods

\begin{tabular}{|c|c|c|c|c|c|c|c|c|c|c|c|c|c|c|c|c|c|c|c|c|}
\hline \multirow[t]{2}{*}{ Bus number } & \multirow{2}{*}{ Source of $\mathrm{H}_{2} \mathrm{O}_{2}$} & \multirow[t]{2}{*}{ Aerosolized period (min) } & \multicolumn{9}{|c|}{ Cl locations } & \multicolumn{9}{|c|}{ Bl locations } \\
\hline & & & 1 & 2 & 3 & 4 & 5 & 6 & 7 & 8 & 9 & 1 & 2 & 3 & 4 & 5 & 6 & 7 & 8 & 9 \\
\hline$\# 1$ & $5 \% \mathrm{H}_{2} \mathrm{O}_{2}+0.005 \% \mathrm{Ag}$ & 30 & + & + & + & + & + & + & + & + & + & - & - & - & - & - & - & - & - & - \\
\hline \#2 & $7 \% \mathrm{H}_{2} \mathrm{O}_{2}$ & 16 & + & + & + & + & + & + & + & + & + & + & + & + & + & + & + & + & + & + \\
\hline \#3 & $7 \% \mathrm{H}_{2}^{2} \mathrm{O}_{2}^{2}$ & 16 & + & + & + & + & + & + & + & + & + & + & + & + & + & + & + & + & + & + \\
\hline \#4 & $5 \% \mathrm{H}_{2} \mathrm{O}_{2}+0.005 \% \mathrm{Ag}$ & 30 & + & + & + & + & + & + & + & + & + & - & - & - & - & - & - & - & - & - \\
\hline \#5 & $5 \% \mathrm{H}_{2} \mathrm{O}_{2}+0.005 \% \mathrm{Ag}$ & 30 & + & + & + & + & + & + & + & + & + & - & - & - & - & - & - & - & - & - \\
\hline$\# 6$ & $7 \% \mathrm{H}_{2} \mathrm{O}_{2}$ & 30 & + & + & + & + & + & + & + & + & + & - & - & - & - & - & - & - & - & - \\
\hline$\# 7$ & $7 \% \mathrm{H}_{2} \mathrm{O}_{2}$ & 30 & + & + & + & + & + & + & + & + & + & - & - & - & - & - & - & - & - & - \\
\hline$\# 8$ & $7 \% \mathrm{H}_{2} \mathrm{O}_{2}$ & 20 & + & + & + & + & + & + & + & + & + & - & - & + & - & - & - & + & + & + \\
\hline$\# 9$ & $7 \% \mathrm{H}_{2} \mathrm{O}_{2}$ & 25 & + & + & + & + & + & + & + & + & + & - & - & + & - & - & - & - & - & - \\
\hline$\# 10$ & $7 \% \mathrm{H}_{2} \mathrm{O}_{2}$ & 20 & + & + & + & + & + & + & + & + & + & + & + & - & - & - & - & + & - & - \\
\hline \#11 & $7 \% \mathrm{H}_{2} \mathrm{O}_{2}$ & 25 & + & + & + & + & + & + & + & + & + & - & - & + & - & - & - & - & + & + \\
\hline$\# 12$ & $7 \% \mathrm{H}_{2} \mathrm{O}_{2}$ & 30 & + & + & + & + & + & + & + & + & + & - & - & - & - & - & - & - & - & - \\
\hline \#13 & $7 \% \mathrm{H}_{2} \mathrm{O}_{2}$ & 30 & + & + & + & + & + & + & + & + & + & - & - & - & - & - & - & - & - & - \\
\hline
\end{tabular}


change resulting from exposure to a process," while the $\mathrm{BI}$ is a "test system containing viable microorganisms providing a specified resistance to a specified sterilization process" [72]. ISO 11138-1:2017 guides the selection and use of Bls for ethylene oxide, moist heat, dry heat, and low-temperature steam formaldehyde but not for HPV and aHP. For the US FDA 510k, a BI is needed to validate the terminal sterilization process of medical devices by HPV with the recommended strain of $G$. stearothermophilus [73]. The finding that $G$. stearothermophilus is the most resistant microorganism to $\mathrm{H}_{2} \mathrm{O}_{2}$ is supported by research [74]. Several studies have suggested using $G$. stearothermophilus spores to validate the aHP process [75], [76]. We used 2.30 $\times 10^{6} \mathrm{G}$. stearothermophilus ATCC 7953 to represent the most resistant strain to the aHP decontamination process and placed Bls in nine locations for each bus in accordance with the room sterilization protocol by the US Environmental Protection Agency (US EPA) that recommends for testing $\mathrm{Bl}$ must contain $\geq 10^{6}$ G. stearothermophilus (ATCC 7953) spores, and test location of Bls must include all corners of the rooms, wall faces, center location, and underneath horizontal surfaces [77]. In our study, all Cls were exposed to $\mathrm{H}_{2} \mathrm{O}_{2}$ at all locations, but this did not guarantee sporicidal efficacy, as determined by Bls. However, Cls will continue to be required to validate the decontamination efficacy since they can be analyzed immediately following the completion of the decontamination process, while Bls require $5-7$ days to be interpreted.

In our study, we achieved a 6-log reduction in sporicidal efficiency, which is equivalent to sterilization. Roberts [82] show that 6-log sporicidal sterilization is more suitable for the terminal sterilization of medical devices compared to room decontamination because ambient surface contamination with microorganisms rarely exceeds a 2-log concentration. To challenge a lower log reduction, the amount of $\mathrm{H}_{2} \mathrm{O}_{2}$ used, the time required for decontamination, and the turnaround time can be decreased. For public bus services, turnaround time is critical. Due to the need for a total of $2 \mathrm{~h}$ of decontamination, it may be reasonable to perform the decontamination at the end of the day. However, shortened decontamination cycle can be operated in daytime during transfer. The aim of this study was to determine the effectiveness of decontamination using a worst-case scenario that could be beneficial during an outbreak. The outcome, which demonstrated high effectiveness, was also beneficial in re-establishing confidence in public transportation.

For the validation and cycle development of the aHP process, we conducted three repetitive tests to demonstrate the reliability of the process. We used only one cycle in contrast to other studies that have found that three cycles of aHP are needed effectiveness (Table 2). In our study, we used both commercials 5\% $\mathrm{H}_{2} \mathrm{O}_{2}+0.005 \% \mathrm{Ag}$ and $7 \% \mathrm{H}_{2} \mathrm{O}_{2}$ concentrations. They were both found to be successful but with different costs, as the cost of the prepared $7 \%$ solution was 10 -fold lower than that of the commercial solution. Given that during the pandemic, public bus operators struggled with a lack of revenue and higher disinfectant costs due to the increased frequency of cleaning and disinfection, a low-cost decontamination process with aHP may be preferable.

Table 2: The studies of room and vehicle decontamination

\begin{tabular}{|c|c|c|c|c|}
\hline Study & $\begin{array}{l}\text { Decontamination } \\
\text { systems }\end{array}$ & Setting & Validations test & Results \\
\hline $\begin{array}{l}\text { Andersen et al. } \\
2006 \text { [78] }\end{array}$ & aHP & ambulance & $\begin{array}{l}2.5 \times 10^{6} \text { Bacillus } \\
\text { atrophaeus } \\
\text { biological } \\
\text { indicator }\end{array}$ & $\begin{array}{l}\text { three cycles of } \\
\text { aHP achieved } \\
6 \text {-log spores } \\
\text { reduction. Total } \\
\text { decontamination } \\
\text { time is } 4-6 \mathrm{~h}\end{array}$ \\
\hline $\begin{array}{l}\text { Havill et al. } \\
2012 \text { [51] }\end{array}$ & $\begin{array}{l}\text { Hydrogen } \\
\text { peroxide vapor } \\
\text { and UVC }\end{array}$ & $\begin{array}{l}\text { patient } \\
\text { room }\end{array}$ & $\begin{array}{l}1 \times 10^{6} \text { Geobacillus } \\
\text { stearothermophilus } \\
\text { biological } \\
\text { indicator }\end{array}$ & $\begin{array}{l}\text { Hydrogen peroxide } \\
\text { vapor was more } \\
\text { effective than } \\
\text { UVC, with a } 6 \text {-log } \\
\text { spores reduction } \\
\text { versus a } 2 \text {-log } \\
\text { spores reduction }\end{array}$ \\
\hline $\begin{array}{l}\text { Kostyuchenko } \\
\text { et al. } 2009 \text { [79] }\end{array}$ & UVC & $\begin{array}{l}\text { metro public } \\
\text { transport } \\
\text { system }\end{array}$ & $\begin{array}{l}\text { Suspension of } \\
\text { Staphylococcus } \\
\text { aureus }\end{array}$ & $\begin{array}{l}\text { A high dose of } \\
\text { UV was required } \\
\left(4500 \mathrm{~J} / \mathrm{m}^{2}\right) \text { for } \\
99 \% \text { disinfection }\end{array}$ \\
\hline $\begin{array}{l}\text { Klaus et al. } \\
2016 \text { [80] }\end{array}$ & $\begin{array}{l}\text { Formaldehyde, } \\
\text { hydrogen } \\
\text { peroxide, and } \\
\text { alcohol }\end{array}$ & Aircraft & Not performed & $\begin{array}{l}\text { Laboratory tests } \\
\text { have revealed that } \\
\text { these disinfectants } \\
\text { were effective and } \\
\text { compatible with } \\
\text { aircraft components }\end{array}$ \\
\hline $\begin{array}{l}\text { Lindsley et al. } \\
2018 \text { [81] }\end{array}$ & UVC & ambulance & $\begin{array}{l}3-4 \times 10^{7} \\
\text { Bacillus subtilis } \\
\text { as a surrogate for } \\
\text { pathogens }\end{array}$ & $\begin{array}{l}\text { The disinfection } \\
\text { efficacy was } \\
\text { varying on } \\
\text { ultraviolet } \\
\text { germicidal } \\
\text { irradiation fixture } \\
\text { position. Based } \\
\text { on these results, } \\
\text { a UVC dose of } \\
52.6 \mathrm{~mJ} / \mathrm{cm}^{2} \\
\text { was required to } \\
\text { inactivate } 99.9 \% \\
\text { of the spores on a } \\
\text { coupon }\end{array}$ \\
\hline
\end{tabular}

The limitation of this study is that it was conducted on a single-size vehicle. A bigger vehicle may require other parameters such as a longer decontamination cycle or the usage of more than one aHP generator, or additional factors as installing fans for assisted distribution of aerosol. During the study, we observed the compatibility of materials, such as fabric seats or interior paint, and we did not find significant issues. Since we conducted this study over a short period, further long-term research is necessary to investigate the material compatibility of the public buses.

\section{Conclusion}

The highly effective disinfection of public transportation with aHP that achieves a sporicidal 6 -log reduction can help reduce the risk of infectious disease transmission. The $100 \mathrm{~min}$ decontamination cycle creates the potential for widespread use in public transportation that demands quick turnaround. 
Automated $\mathrm{H}_{2} \mathrm{O}_{2}$ aerosolization system has many advantages, including ease of use, environmental friendliness, versatility, reliability, low cost of machine, and operations. The important point is that validations are required prior to actual use in any area or room. Validation is based on the effectiveness of decontamination and turnaround time. The automated system is safe for the workers because it does not require human beings to operate and contributes to the reduction of the effects of human error.

This decontamination procedure is applicable to public buses, but it must be emphasized that it is a supplement and cannot be used in place of cleaning. Enhancing the disinfection of public buses can help mitigate the risk of infectious transmission and regain trust in public transportation during and after a pandemic. This is the "next normal" in which public transport operators compete for sanitation to gain and retain regular passengers.

\section{References}

1. Jenelius E, Cebecauer M. Impacts of COVID-19 on public transport ridership in Sweden: Analysis of ticket validations, sales, and passenger counts. Transp Res Interdiscip Perspect. 2020; 8:100242. https://doi.org/10.1016/j.trip.2020.100242 PMid:34173478

2. Bucsky P. Modal share changes due to COVID-19: The case of Budapest. Transp Res Interdiscip Perspect. 2020; 8:100141. https://doi.org/10.1016/j.trip.2020.100141

PMid:34171021

3. de Haas M, Faber R, Hamersma M. How COVID-19 and the Dutch 'intelligent lockdown' change activities, work, and travel behavior: Evidence from longitudinal data in the Netherlands. Transp Res Interdiscip Perspect. 2020; 6:100150. https://doi. org/10.1016/j.trip.2020.100150

PMid:34171019

4. Wielechowski M, Czech K, Grzęda $Ł$. Decline in mobility: Public transport in Poland in the time of the COVID-19 Pandemic. Economies. 2020; 8(4):78.

5. Borkowski $P$, Jażdżewska-Gutta $M$, Szmelter-Jarosz A. Lockdowned: Everyday mobility changes in response to COVID19. J Transp Geogr. 2021; 90:102906.

6. Zhang J, Hayashi Y, Frank LD. COVID-19 and transport: Findings from a world-wide expert survey. Transp Policy (Oxf). 2021; 103:68-85. https://doi.org/10.1016/j.tranpol.2021.01.011 PMid:33519127

7. Kaske M. New York MTA Says Federal Aid Deal Avoids "Devastating" Cuts; 2020. Available from: https://www.bloomberg. com/news/articles/2020-12-21/new-york-mta-says-federal-aiddeal-prevents-devastating-cuts. [Last accessed on 2021 May 09].

8. Mehmet S. NEWS Coronavirus Support for UK Buses and Trams Extended to $£ 700$ Million; 2020. Available from: https://www.intelligenttransport.com/transport-news/103814/ coronavirus-support-for-uk-buses-and-trams-extended-to-700million. [Last accessed on 2021 May 09].

9. Tsang D. Battered by the Coronavirus Pandemic, Hong Kong's MTR Corporation Warns of Losses of HK\$4.8 Billion in 2020; 2021. Available from: https://www.sg.news.yahoo.com/ battered-coronavirus-pandemic-hong-kong-151205273.html. [Last accessed on 2021 May 09].

10. Przybylowski A, Stelmak S, Suchanek M. Mobility behavior in view of the impact of the COVID-19 pandemic-public transport users in gdansk case study. Sustainability. 2021; 13(1):364.

11. Kopsidas A, Milioti C, Kepaptsoglou K, Vlachogianni El. How did the COVID-19 pandemic impact traveler behavior toward public transport? The case of Athens, Greece. Transp Lett. 2021; 13(5-6):1-9.

12. Shen Y, Li C, Dong H, Wang Z, Martinez L, Sun Z, et al. Community outbreak investigation of SARS-CoV-2 transmission among bus riders in Eastern China. JAMA Intern Med. 2020; 180(12):166571. https://doi.org/10.1001/jamainternmed.2020.5225 PMid:32870239

13. Luo K, Lei Z, Hai Z, Xiao S, Rui J, Yang H, et al. Transmission of SARS-CoV-2 in public transportation vehicles: A case study in Hunan province, China. Open Forum Infect Dis. 2020; 7(10):ofaa430. https://doi.org/10.1093/ofid/ofaa430 PMid:33123609

14. Yang N, Shen $Y$, Shi C, Ma AHY, Zhang X, Jian X, et al. In-flight transmission cluster of COVID-19: A retrospective case series. Infect Dis. 2020; 52(12):891-901. https://doi.org/10.1080/23744 235.2020.1800814

PMid:32735163

15. Khanh NC, Thai PQ, Quach HL, Thi NA, Dinh PC, Duong TN et al. Transmission of SARS-CoV 2 during long-haul flight. Emerg Infect Dis. 2020; 26(11):2617-24.

PMid:32946369

16. World Health Organization. Modes of Transmission of Virus Causing COVID-19: Implications for IPC Precaution Recommendations: Scientific Brief, 27 March 2020. Geneva: World Health Organization; 2020.

17. Rheinbaben F, Schünemann $S$, Gross $T$, Wolff M. Transmission of viruses through contact in a household setting: Experiments using bacteriophage $\phi \times 174$ as a model virus. J Hosp Infect. 2000; 46(1):61-6. https://doi.org/10.1053/jhin.2000.0794 PMid: 11023725

18. Lei H, Li Y, Xiao S, Yang X, Lin C, Norris SL, et al. Logistic growth of a surface contamination network and its role in disease spread. Sci Rep. 2017; 7(1):14826. https://doi.org/10.1038/ s41598-017-13840-z

PMid:29093534

19. Ben-Shmuel A, Brosh-Nissimov T, Glinert I, Bar-David E, Sittner A, Poni R, et al. Detection and infectivity potential of severe acute respiratory syndrome coronavirus 2 (SARS-CoV-2) environmental contamination in isolation units and quarantine facilities. Clin Microbiol Infect. 2020; 26(12):1658-62. https://doi. org/10.1016/j.cmi.2020.09.004

PMid:32919072

20. Cheng VC, Wong SC, Chan VW, So SY, Chen JH, Yip CC, et al. Air and environmental sampling for SARS-CoV-2 around hospitalized patients with Coronavirus disease 2019 (COVID-19). Infect Control Hosp Epidemiol. 2020; 41(11):125865. https://doi.org/10.1017/ice.2020.282

PMid:32507114

21. Ong SW, Lee PH, Tan YK, Ling LM, Ho BC, Ng CG, et al. Environmental contamination in a Coronavirus disease 2019 (COVID-19) intensive care unit-What is the risk? Infect Control Hosp Epidemiol. 2020; 42(6):669-77. https://doi.org/10.1017/ ice.2020.1278

PMid:33081858

22. Peyrony O, Ellouze S, Fontaine JP, Thegat-Le Cam M, Salmona M, Feghoul L, et al. Surfaces and equipment contamination by severe acute respiratory syndrome Coronavirus 2 (SARS-CoV-2) in the emergency department at a 
university hospital. Int J Hyg Environ Health. 2020; 230:113600. https://doi.org/10.1016/j.ijheh.2020.113600 PMid:32799101

23. Zhou J, Otter JA, Price JR, Cimpeanu C, Garcia DM, Kinross J, et al. Investigating SARS-CoV-2 surface and air contamination in an acute healthcare setting during the peak of the COVID-19 pandemic in London. Clin Infect Dis. 2020;ciaa905. https://doi. org/10.1093/cid/ciaa905

PMid:32634826

24. Abrahão JS, Sacchetto $L$, Rezende IM, Rodrigues RAL, Crispim APC, Moura C, et al. Detection of SARS-CoV-2 RNA on public surfaces in a densely populated urban area of Brazil: A potential tool for monitoring the circulation of infected patients. Sci Total Environ. 2021; 766:142645. https://doi.org/10.1016/j. scitotenv.2020.142645

PMid:33069469

25. Amoah ID, Pillay L, Deepnarian N, Awolusi O, Pillay K, Ramlal P, et al. Detection of SARS-CoV-2 on Contact Surfaces Within Shared Sanitation Facilities and Assessment of the Potential Risks for COVID-19 Infections, Research Square; 2020.

26. Döhla M, Wilbring G, Schulte B, Kümmerer BM, Diegmann C, Sib E, et al. SARS-CoV-2 in Environmental Samples of Quarantined Households, medRxiv; 2020.

27. Harvey AP, Fuhrmeister ER, Cantrell ME, Pitol AK, Swarthout JM, Powers JE, et al. Longitudinal monitoring of SARS-CoV-2 RNA on high-touch surfaces in a community setting. Environ Sci Technol Lett. 2021; 8(2):168-75. https://doi.org/10.1021/acs. estlett.0c00875

PMid:34192125

28. Maestre JP, Jarma D, Yu JR, Siegel JA, Horner SD, Kinney KA. Distribution of SARS-CoV-2 RNA signal in a home with COVID19 positive occupants. Sci Total Environ. 2021; 778:146201. https://doi.org/10.1016/j.scitotenv.2021.146201 PMid:34030356

29. Wong JC, Hapuarachchi HC, Arivalan S, Tien WP, Koo C, Mailepessov D, et al. Environmental contamination of SARSCoV-2 in a non-healthcare setting. Int J Environ Res Public Health. 2021; 18(1):117. https://doi.org/10.3390/ijerph18010117 PMid:33375308

30. van Doremalen N, Bushmaker T, Morris DH, Holbrook MG, Gamble A, Williamson BN, et al. Aerosol and surface stability of SARS-CoV-2 as compared with SARS-CoV-1. N Engl J Med. 2020; 382(16):1564-7. https://doi.org/10.1056/NEJMc2004973 PMid:32182409

31. Xie C, Zhao H, Li K, Zhang Z, Lu X, Peng H, et al. The evidence of indirect transmission of SARS-CoV-2 reported in Guangzhou, China. BMC Public Health. 2020; 20(1):1202. https://doi. org/10.1186/s12889-020-09296-y PMid:32758198

32. Cai J, Sun W, Huang J, Gamber M, Wu J, He G. Indirect virus transmission in cluster of COVID-19 cases, Wenzhou, China, 2020. Emerg Infect Dis. 2020; 26(6):1343-5. https://doi. org/10.3201/eid2606.200412 PMid:32163030

33. Mondelli MU, Colaneri M, Seminari EM, Baldanti F, Bruno R. Low risk of SARS-CoV-2 transmission by fomites in real-life conditions. Lancet Infect Dis. 2021; 21(5):e112. https://doi. org/10.1016/S1473-3099(20)30678-2

PMid:33007224

34. Goldman E. Exaggerated risk of transmission of COVID-19 by fomites. Lancet Infect Dis. 2020; 20(8):892-3. https://doi. org/10.1016/S1473-3099(20)30561-2 PMid:32628907

35. Santarpia JL, Rivera DN, Herrera VL, Morwitzer MJ, Creager HM, Santarpia GW, et al. Aerosol and surface contamination of SARS-CoV-2 observed in quarantine and isolation care. Sci Rep. 2020; 10(1):12732. https://doi. org/10.1038/s41598-020-69286-3

\section{PMid:32728118}

36. Chen T. Fomites and the COVID-19 Pandemic: An Evidence Review on its Role in Viral Transmission; 2021. Available from: https://www.ncceh.ca/sites/default/files/fomites $\% 20$ and $\% 20$ covid-19\%20march\%2022\%20final\%20in\%20template-revised. pdf. [Last accessed on 2021 May 09].

37. Boone SA, Gerba CP. Significance of fomites in the spread of respiratory and enteric viral disease. Appl Environ Microbiol. 2007; 73(6):1687-96. https://doi.org/10.1128/AEM.02051-0 PMid: 17220247

38. Desai R, Pannaraj PS, Agopian J, Sugar CA, Liu GY, Miller LG. Survival and transmission of community-associated methicillin-resistant Staphylococcus aureus from fomites. Am J Infect Control. 2011; 39(3):219-25. https://doi.org/10.1016/j. ajic.2010.07.005

PMid:21458684

39. Wu HM, Fornek M, Schwab KJ, Chapin AR, Gibson K, Schwab E, et al. A norovirus outbreak at a long-term-care facility: The role of environmental surface contamination. Infect Control Hosp Epidemiol. 2005; 26(10):802-10. https://doi. org/10.1086/502497

PMid:16276954

40. Lei $\mathrm{H}$, Li Y, Xiao S, Lin CH, Norris SL, Wei D, et al. Routes of transmission of influenza A H1N1, SARS CoV, and norovirus in air cabin: Comparative analyzes. Indoor Air. 2018; 28(3):394403. https://doi.org/10.1111/ina.12445

PMid:29244221

41. Telles CR, Roy A, Ajmal MR, Mustafa SK, Ahmad MA, de la Serna JM, et al. The Impact of COVID-19 management policies tailored to airborne SARS-CoV-2 transmission: Policy analysis. JMIR Public Health Surveill. 2021; 7(4):e20699. https://doi. org/10.2196/20699

PMid:33729168

42. Carling PC, Briggs JL, Perkins J, Highlander D. Improved cleaning of patient rooms using a new targeting method. Clin Infect Dis. 2006; 42(3):385-8. https://doi.org/10.1086/499361 PMid:16392086

43. Gordon L, Bruce N, Suh KN, Roth V. Evaluating and operationalizing an environmental auditing program: A pilot study. Am J Infect Control. 2014; 42(7):702-7. https://doi. org/10.1016/j.ajic.2014.04.007

PMid:24969123

44. Boyce JM. Modern technologies for improving cleaning and disinfection of environmental surfaces in hospitals. Antimicrob Resist Infect Control. 2016; 5(1):10. https://doi.org/10.1186/ s13756-016-0111-x

PMid:27069623

45. Kim SC, Kwak DB, Kuehn T, Pui DY. Characterization of handheld disinfectant sprayers for effective surface decontamination to mitigate severe acute respiratory Coronavirus virus 2 (SARSCoV-2) transmission. Infect Control Hosp Epidemiol. 2021; 42(7):901-3. https://doi.org/10.1017/ice.2020.1423 PMid:33436119

46. Roth $\mathrm{K}$, Michels $\mathrm{W}$. Inter-hospital trials to determine minimal cleaning performance according to the guideline by DGKH, DGSV and AKI. Zentr Steril. 2005; 13(2):106-16.

47. Ríos-Castillo AG, Umaña FF, Rodríguez-Jerez JJ. Long-term antibacterial efficacy of disinfectants based on benzalkonium chloride and sodium hypochlorite tested on surfaces against resistant gram-positive bacteria. Food Control. 2018; 93:219-25.

48. Pereira BM, Tagkopoulos I, Vieille C. Benzalkonium chlorides: Uses, regulatory status, and microbial resistance. Appl Environ 
Microbiol. 2019; 85(13):e00377-19. https://doi.org/10.1128/ AEM.00377-19

PMid:31028024

49. World Health Organization. IARC Monographs on the Evaluation of Carcinogenic Risks to Humans. Volume 88: Formaldehyde, 2-Butoxyethanol and 1-Tert-Butoxypropan-2-ol. Lyon (FR). 2006.

50. Rutala WA, Weber DJ. Guideline for Disinfection and Sterilization in Healthcare Facilities; 2008.

51. Havill NL, Moore BA, Boyce JM. Comparison of the microbiological efficacy of hydrogen peroxide vapor and ultraviolet light processes for room decontamination. Infect Control Hosp Epidemiol. 2012; 33(5):507-12. https://doi. org/10.1086/665326

PMid:22476278

52. Zinatloo-Ajabshir S, Ghasemian N, Mousavi-Kamazani M, Salavati-Niasari M. Effect of zirconia on improving NOx reduction efficiency of Nd2Zr2O7 nanostructure fabricated by a new, facile and green sonochemical approach. Ultrason Sonochem. 2021; 71:105376. 10.1016/j.ultsonch.2020.105376

PMid:33142222

53. Zinatloo-Ajabshir S, Baladi M, Salavati-Niasari M. Enhanced visible-light-driven photocatalytic performance for degradation of organic contaminants using PbWO4 nanostructure fabricated by a new, simple, and green sonochemical approach. Ultrason Sonochem. 2021; 72:105420. https://doi.org/10.1016/j. ultsonch.2020.105420

PMid:33385636

54. Otter JA, Yezli S, Barbut F, Perl TM. An overview of automated room disinfection systems: When to use them and how to choose them. In: Decontamination in Hospitals and Healthcare. Tamil Nadu: Elsevier; 2020. p. 323-69.

55. Boyce JM, Havill NL, Otter JA, McDonald LC, Adams NM, Cooper $\mathrm{T}$, et al. Impact of hydrogen peroxide vapor room decontamination on Clostridium difficile environmental contamination and transmission in a healthcare setting. Infect Control Hosp Epidemiol. 2008; 29(8):723-9. https://doi. org/10.1086/589906

PMid: 18636950

56. Otter JA, French GL. Survival of nosocomial bacteria and spores on surfaces and inactivation by hydrogen peroxide vapor. J Clin Microbiol. 2009; 47(1):205-7. https://doi.org/10.1128/ JCM.02004-08

PMid:18971364

57. Holmdahl T, Walder M, Uzcátegui N, Odenholt I, Lanbeck P, Medstrand $\mathrm{P}$, et al. Hydrogen peroxide vapor decontamination in a patient room using feline calicivirus and murine norovirus as surrogate markers for human norovirus. Infect Control Hosp Epidemiol. 2016; 37(5):561-6. https://doi.org/10.1017/ ice.2016.15

PMid:26861195

58. Holmdahl T, Lanbeck P, Wullt M, Walder M. A head-to-head comparison of hydrogen peroxide vapor and aerosol room decontamination systems. Infect Control Hosp Epidemiol. 2011; 32(9):831-6. https://doi.org/10.1086/661104

PMid:21828962

59. Beswick AJ, Farrant J, Makison C, Gawn J, Frost G, Crook B, et al. Comparison of multiple systems for laboratory whole room fumigation. Appl Biosaf. 2011; 16(3):139-57.

60. Fu TY, Gent P, Kumar V. Efficacy, efficiency, and safety aspects of hydrogen peroxide vapour and aerosolized hydrogen peroxide room disinfection systems. J Hosp Infect. 2012; 80(3):199-205. https://doi.org/10.1016/j.jhin.2011.11.019 PMid:22306442

61. Ali S, Muzslay M, Bruce M, Jeanes A, Moore G, Wilson AP. Efficacy of two hydrogen peroxide vapour aerial decontamination systems for enhanced disinfection of meticillin-resistant Staphylococcus aureus, Klebsiella pneumoniae and Clostridium difficile in single isolation rooms. J Hosp Infect. 2016; 93(1):707. https://doi.org/10.1016/j.jhin.2016.01.016 PMid:26944907

62. Kümin D, Albert MG, Weber B, Summermatter K. The hitchhiker's guide to hydrogen peroxide fumigation, Part 1: Introduction to hydrogen peroxide fumigation. Appl Biosaf. 2020; 25(4):214-24.

63. Kümin D, Albert MG, Summermatter K. Case Study: Room fumigation using aerosolized hydrogen peroxide-a versatile and economic fumigation method. Appl Biosaf. 2019; 24(4):200-6.

64. Cervantes Trejo A, Castañeda ID, Rodríguez AC, Andrade Carmona VR, Mercado MdPC, Vale LS, et al. Hydrogen peroxide as an adjuvant therapy for COVID-19: A case series of patients and caregivers in the Mexico city metropolitan area. Evid Based Complement Alternat Med. 2021; 2021:5592042. https://doi.org/10.1155/2021/5592042

PMid:34335827

65. International Agency for Research on Cancer. Hydrogen Peroxide. IARC Monographs on the Evaluation of Carcinogenic Risk of Chemicals To Humans: Allyl Compounds, Aldehydes, Epoxides and Peroxides. Vol. 36. Lyon: IARC; 1985. p. 285-314.

66. U.S. Food and Drug Administration. FDA Warns against Internal use of High-Strength Hydrogen Peroxide, 2006 August 7; 2021. Available from: https://www.medscape.com/viewarticle/541868. [Last accessed on 2021 Aug 07].

67. Mastrangelo G, Zanibellato R, Fedeli U, Fadda E, Lange JH. Exposure to hydrogen peroxide at TLV level does not induce lung function changes: A longitudinal study. Int J Environ Health Res. 2005; 15(4):313-7.

68. Occupational Safety and Health Administration. 29 CFR 1910.1000 Table Z-1-Table Z-1 Limits for Air Contaminants; 2017. Available from: https://www.osha.gov/laws-regs/ regulations/standardnumber/1910/1910.1000tablez1. [Last accessed on 2021 May 11].

69. Linley E, Denyer SP, McDonnell G, Simons C, Maillard JY. Use of hydrogen peroxide as a biocide: New consideration of its mechanisms of biocidal action. J Antimicrob Chemother. 2012; 67(7):1589-96.

PMid:22532463

70. Unger-Bimczok B, Kottke V, Hertel C, Rauschnabel J. The influence of humidity, hydrogen peroxide concentration, and condensation on the inactivation of Geobacillus stearothermophilus spores with hydrogen peroxide vapor. J Pharm Innov. 2008; 3(2):123-33.

71. Imai K, Watanabe S, Oshima Y, Kokubo M, Akers J. A new approach to vapor hydrogen peroxide decontamination of isolators and cleanrooms. Pharm Eng. 2006; 26(3):96-104.

72. International Organization for Standardization. Sterilization of Health Care Products-Vocabulary of Terms Used in Sterilization and Related Equipment and Process Standards. Geneva, Switzerland: International Organization for Standardization; 2018.

73. U.S. Food and Drug Administration. Biological Indicator (BI) Premarket Notification [510(k)] Submissions; 2007. Available from: https://www.fda.gov/regulatory-information/searchfda-guidance-documents/biological-indicator-bi-premarketnotification-510k-submissions. [Last accessed on 2021 May 16].

74. Castro L, Lourenço F, Pinto T. Assessment of biological indicators in the validation of isolator decontamination with hydrogen peroxide. Rev Ciênc Farm Básica Apl. 2011; 32(3):335-9.

75. Kümin D, Albert MG, Weber B, Summermatter K. The Hitchhiker's guide to hydrogen peroxide fumigation, Part 2: Verifying and validating hydrogen peroxide fumigation cycles. Appl Biosaf. 2021; 26(1):42-51.

76. Vanhecke $P$, Sigwarth $V$, Moirandat C. A potent and safe $\mathrm{H}_{2} \mathrm{O}_{2}$ fumigation approach. PDA J Pharm Sci Technol. 2012; 
66(4):354-70. https://doi.org/10.5731/pdajpst.2012.00870 PMid:22767884

77. US Environmental Protection Agency Office of Pesticide Programs. Protocol for Room Sterilization by Fogger Application; 2015. Available from: https://www.epa.gov/sites/ production/files/2015-09/documents/room-sterilization.pdf. [Last accessed on 2021 May 16].

78. Andersen $B$, Rasch $M$, Hochlin $K$, Jensen FH, Wismar $\mathrm{P}$, Fredriksen JE. Decontamination of rooms, medical equipment and ambulances using an aerosol of hydrogen peroxide disinfectant. J Hosp Infect. 2006; 62(2):149-55. https://doi. org/10.1016/j.jhin.2005.07.020

PMid:16337307

79. Kostyuchenko S, Khan A, Volkov S, Giller H. UV disinfection in Moscow metro public transport systems. IUVA News. 2009; 11(1):16-23.
80. Klaus J, Gnirs P, Hölterhoff S, Wirtz A, Jeglitza M, Gaber W, et al. Disinfection of aircraft. Bundesgesundheitsblatt Gesundheitsforschung Gesundheitsschutz. 2016; 59(12):15448. https://doi.org/10.1007/s00103-016-2460-2

PMid:27785522

81. Lindsley WG, McClelland TL, Neu DT, Martin SB, Mead KR, Thewlis RE, et al. Ambulance disinfection using ultraviolet germicidal irradiation (UVGI): Effects of fixture location and surface reflectivity. J Occup Environ Hyg. 2018; 15(1):1-12. https://doi.org/10.1080/15459624.2017.1376067

PMid:29059039

82. Roberts CG. Hydrogen peroxide vapor and aerosol room decontamination systems. Infect Control Hosp Epidemiol. 2012; 33(3):312; author reply 312-3. https://doi.org/10.1086/664043 PMid:22314074 